\title{
PENELITIAN KUALITATIF BIDANG ILMU HUKUM DALAM PERSFEKTIF FILSAFAT KONSTRUKTIVIS
}

\author{
Tengku Erwinsyahbana \\ Ramlan
}

\author{
Fakultas Hukum Universitas Muhammadiyah Sumatera Utara \\ E-mail: erwin6768@gmail.com
}

\begin{abstract}
Abstrak
Penelitian merupakan sarana pengembangan ilmu pengetahuan dan teknologi, yang hasilnya dipergunakan bagi kehidupan manusia. Dalam penelitian ilmu sosial, termasuk ilmu hukum, dikenal 2 (dua) jenis metode penelitian, yaitu metode kuantitatif dan kualitatif, dan walaupun masing-masingnya terdapat perbedaan karakteristik metode yang digunakan, tetapi terdapat prinsip-prinsip umum yang harus dipahami oleh setiap peneliti, seperti: validitas dari hasil capaian dan prinsip-prinsip kejujuran ilmiah. Penelitian kualitatif mengkonstruksikan realitas dan memahami maknanya, sehingga lebih memperhatikan proses, peristiwa dan otentisitasnya. Penelitian kualitatif pada dasarnya ditujukan untuk memahami fenomena-fenomena sosial dari sudut pandang partisipan, dan yang diteliti adalah kondisi objek alamiahnya, sehingga karakteristik penelitian kualitatif menggunakan lingkungan alamiah sebagai sumber data, memiliki sifat deskriptif analitis, lebih mengutamakan pada proses bukan hasil, bersifat induktif, dan mengutamakan pemaknaan. Hal ini sesuai dengan pemikiran filsafat konstruktivis yang beranggapan bahwa pengetahuan adalah hasil dari konstruksi (bentukan) manusia itu sendiri, sedangkan manusia mengkonstruksikan pengetahuannya melalui interaksi dengan objek, fenomena, pengalaman dan lingkungannya.
\end{abstract}

\section{Kata Kunci: Filsafat Konstruktivis, Ilmu Hukum, Penelitian Kualitatif.}

\section{A. Pendahuluan}

Penelitian dan ilmu pengetahuan dapat diibaratkan sebagai dua sisi dari satu mata uang, yang tidak mampu memisahkan diri antara yang satu sama dengan lainnya atau sama-sama saling meninggalkan. Penelitian akan berkurang maknanya kecuali digunakan untuk kebutuhan ilmu pengetahuan, sebaliknya ilmu pengetahuan akan terhenti tanpa penelitian. Penelitian merupakan cara-cara sistematis untuk menjawab masalah yang diteliti, sedangkan sistematis merupakan kata kunci yang berkaitan dengan metode ilmiah, berarti adanya prosedur yang ditandai dengan keteraturan dan ketuntasan (Jonathan Sarwono, 2006: 15). 
Ilmu pengetahuan pada hakikatnya timbul karena adanya hasrat ingin tahu dalam diri manusia, yang muncul karena banyak hal-hal atau aspek-aspek kehidupan yang masih gelap atau belum terungkap dan manusia ingin mengetahui segi kebenaran dari kegelapan. Setelah manusia memperoleh pengetahuan tentang sesuatu, maka kepuasannya segera akan disusul lagi dengan suatu kecenderungan, serta keinginan untuk lebih mengetahui lagi. Hal ini terjadi karena apa yang menjelma di hadapan manusia, ditanggapinya sebagai sesuatu yang statis dan sekaligus dinamis. Dalam usahanya untuk mencari jawaban yang benar atas kenyataan yang dihadapinya, maka manusia dapat menempuh berbagai macam cara, baik yang dianggap sebagai usaha yang tidak ilmiah, maupun usaha yang dapat dikualifikasikan sebagai kegiatan-kegiatan ilmiah.

Adakalanya manusia mencari kebenaran melalui pemikiran yang kritis ataupun berdasarkan pengalaman. Usaha ini belum merupakan kegiatan ilmiah yang seutuhnya, oleh karena itu tidak jarang kegiatan tersebut mengabaikan sistematika, metode tertentu, serta tidak dilandaskan pada kekuatan pemikiran yang ilmiah. Usaha lain adalah melalui penelitian secara ilmiah, artinya menggunakan suatu metode yang bertujuan untuk mempelajari satu atau beberapa gejala, dengan jalan menganalisisnya dan dengan mengadakan pemeriksaan yang mendalam terhadap fakta tersebut, kemudian mengusahakan suatu pemecahan atas masalah-masalah yang ditimbulkan oleh suatu fakta.

Penelitian secara ilmiah, dilakukan oleh manusia untuk menyalurkan hasrat ingin tahu yang telah mencapai taraf ilmiah, yang disertai dengan suatu keyakinan bahwa setiap gejala akan dapat ditelaah dan dicari hubungan sebab akibatnya atau kecenderungan-kecenderungan yang ditimbulkannya, dan oleh sebab itu diperlukan suatu metoda ilmiah yang merupakan prosedur dalam mendapatkan pengetahuan yang disebut ilmu. Jujun S. Suriasumantri (1999: 119), mengatakan bahwa ilmu merupakan pengetahuan yang didapatkan melalui metoda ilmiah.

Secara komprehensif, Arief Sidharta (2007), mengatakan bahwa disiplin ilmiah adalah upaya rasional-sistematikal-metodologikal terargumentasi yang bersaranakan konsep-konsep yang khusus dibentuk untuk itu, memperoleh 
pengetahuan dan pemahaman tentang realitas atau bagian dari realitas dan menata hasil-hasilnya ke dalam sebuah sistem, dan oleh sebab itu menurut Ronny Hanitijo Soemitro (2001: 45), dikatakan bahwa penelitian bertujuan untuk menemukan, mengembangkan atau menguji kebenaran suatu pengetahuan. Menemukan berarti berusaha untuk memperoleh sesuatu untuk mengisi kekurangan atau kekosongan. Mengembangkan berarti memperluas dan menggali lebih dalam sesuatu yang sudah ada. Menguji kebenaran dilakukan bila fakta yang ada tersebut, masih atau menjadi diragu-ragukan kebenarannya.

Manusia selalu akan bertanya akan hakikat sesuatu, dan jika dalam diri manusia muncul pertanyaan-pertanyaan mendasar (seperti: apa, bagaimana atau mengapa), maka manusia selalu akan berusaha memperoleh jawabannya dan pada saat itu dapat dikatakan bahwa dirinya telah berfilsafat. Filsafat adalah istilah yang berasal dari bahasa Yunani, yaitu filosofia, yang berarti melihat segala sesuatu dengan perhatian atau minat ataupun berarti berpikir tentang segala sesuatu dan keadaan yang berpikir seperti itu disadarinya (Judistira K. Garna, 2006: 1). Filsafat adalah refleksi tentang landasan dari kenyataan (Arief Sidharta, 2007: 1). Filsafat harus memenuhi syarat rasionalitas, berarti penalaran-penalaran kefilsafatan harus sah secara logikal (memenuhi aturan-aturan yang ditetapkan oleh logika) dan pemilihan premis-premis serta formulasi kesimpulan harus mempertahankan suatu struktur terbuka (Arief Sidharta, 2007: 2).

Dalam berfilsafat harus menggunakan metode ilmiah, dan metode ilmiah yang dimaksud adalah metodologi penelitian yang pada hakikatnya untuk mengkaji (mempelajari) sisi kelebihan dan kekurangan ilmu dalam rangka mendapatkan dan mengembangkan ilmu secara ilmiah melalui prinsip-prinsip metode ilmiah. Melalui kegiatan berfilsafat berarti kajian yang diperlihatkan adalah usaha untuk mengkaji (mempelajari) hakikat ilmu dari tiga sisi yaitu: (1) sisi obyek yang ditelaah ilmu dengan landasan ontologi; (2) sisi proses, prosedur, cara atau teknik untuk mendapatkan/mengembangkan ilmu dengan landasan epistemologi; dan (3) sisi kegunaan ilmu dengan landasan aksiologi (Sunny, 2000: 36). Sehubungan dengan usaha untuk mendapatkan dan mengembangkan ilmu, maka kajian filsafat terhadap hakikat ilmu dilakukan melalui proses, prosedur, 
cara atau teknik dengan landasan epistemologi secara ilmiah, yaitu melalui suatu cara yang disebut metode ilmiah.

Penelitian tentunya harus dirancangkan sedemikian rupa, sehingga peneliti dapat mempunyai pedoman arah yang jelas sesuai dengan tujuan yang telah ditetapkan, mulai dari kegiatan pengumpulan data, sampai pada tahapan analisis data yang terkumpul. Rancangan penelitian atau dalam istilah lain disebut dengan desain penelitian adalah rencana atau strategi yang digunakan untuk menjawab masalah dan mengukur variabel penelitian. Desain penelitian dapat diartikan sebagai proses yang diperlukan untuk merencanakan dan melaksanakan penelitian, yang secara sempit hanya mengenai pengumpulan dan analisis data, sehingga fungsinya adalah sebagai fasilitas bagi tujuan penelitian dan bersifat prosedural.

Terkait dengan desain penelitian, maka ada 2 (dua) metode yang dapat dipilih, yaitu: (1) metode kuantitatif; dan (2) metode kualitatif. Menurut Sugiyono (2012: 7), dikatakan bahwa metode penelitian kuantitatif dapat diartikan sebagai metode penelitian yang berlandaskan pada filsafat positivisme, digunakan untuk meneliti pada populasi atau sampel tertentu. Teknik pengambilan sampel pada umumnya dilakukan secara random, pengumpulan data menggunakan instrumen penelitian, analisis data bersifat kuantitatif/statistik dengan tujuan untuk menguji hipotesis yang telah ditetapkan, sedangkan metode kualitatif menurut Burhan Ashshofa (1996: 20-21), memusatkan perhatian pada prinsip-prinsip umum yang mendasari perwujudan satuan-satuan gejala yang ada dalam kehidupan manusia, atau pola yang dianalisis adalah gejala sosial budaya dengan kebudayaan dari masyarakat yang bersangkutan untuk memperoleh gambaran mengenai pola yang berlaku.

Metode kuantitatif sering juga disebut sebagai metode tradisional, positivistik, ilmiah/scientific dan metode discovery. Disebut sebagai metode positivistik karena berlandaskan pada filsafat positivism, disebut sebagai metode ilmiah (scientific), karena metode ini telah memenuhi kaidah-kaidah ilmiah yaitu konkrit, empiris, obyektif, terukur, rasional dan sistematis, dan disebut sebagai metode discovery, karena dengan metode ini dapat ditemukan dan dikembangkan 
berbagai ilmu pengetahuan baru (Afid Burhanuddin, https://afidburhanuddin. wordpress.com.: diakses tanggal 25 Mei 2016)

Metode penelitian kualitatif merupakan metode penelitian yang lebih menekankan pada aspek pemahaman secara mendalam terhadap suatu masalah dari pada melihat permasalahan untuk penelitian generalisasi, yang menggunakan teknik analisis mendalam (in-depth analysis), yaitu mengkaji masalah secara kasus perkasus, karena metodologi kualitatif meyakini bahwa sifat suatu masalah yang satu akan berbeda dengan sifat dari masalah lainnya. Menurut teori penelitian kualitatif, agar penelitinya dapat betul-betul berkualitas, maka data yang dikumpulkan harus lengkap, yaitu berupa data primer dan data sekunder. Data primer adalah data dalam bentuk verbal atau kata-kata yang diucapkan secara lisan, gerak-gerik atau perilaku yang dilakukan oleh subjek yang dapat dipercaya, dalam hal ini adalah subjek penelitian (informan) yang berkenaan dengan variabel yang diteliti, sedangkan data sekunder adalah data yang diperoleh dari dokumen-dokumen grafis (tabel, catatan, notulen rapat, dan lain-lain), fotofoto, film, rekaman video, benda-benda, dan lain-lain yang dapat memperkaya data primer (Afid Burhanuddin, https://afidburhanuddin.wordpress.com.: diakses tanggal 25 Mei 2016), sehingga tujuan dari metode kualitatif bukan generalisasi, tetapi pemahaman secara mendalam terhadap suatu masalah.

Penelitian kualitatif dinamakan juga dengan pendekatan konstruktivis, naturalistis atau interpretatif (constructivist, naturalistic, or interpretative approach), atau perspektif postmodern. Metode penelitian kualitatif dengan pendekatan konstruktivis dapat digunakan dalam berbagai bidang ilmu sosial, dan termasuk di antaranya adalah bidang ilmu hukum. Perlu dipahami bahwa penelitian kualitatif merupakan paradigma penelitian yang menekankan pada pemahaman mengenai masalah-masalah dalam kehidupan sosial berdasarkan kondisi realitas atau natural setting yang holistis, kompleks dan rinci. Penelitianpenelitian dengan pendekatan induktif yang mempunyai tujuan penyusunan konstruksi teori atau hipotesis melalui pengungkapan fakta adalah contoh tipe penelitian yang menggunakan paradigma kualitatif (Yuliati Natalia, http://ulieanak-ragil.blogspot.co.id.: diakses diakses tanggal 25 Mei 2016), dan khusus 
dalam bidang ilmu hukum, perlu kiranya dilakukan kajian yang terkait dengan metode penelitian kualitatif dalam paradigma filsafat konstruktivis.

\section{B. Pembahasan}

Filsafat ilmu pada dasarnya merujuk kepada proses dan metode untuk memperoleh pengetahuan secara ilmiah yaitu melalui metode ilmiah atau metode penelitian. Sehubungan hal ini, ilmu pengetahuan diperoleh dengan upaya sadar, dengan metode tertentu dan prosedur tertentu yang kebenarannya dapat diuji. Berdasarkan hal tersebut, maka ilmu itu sifatnya inter-subyektif dan reproduktif. Inter-subyektif artinya dapat dicapai oleh setiap orang yang mampu memenuhi penguasaan prosedur dan metodenya. Reproduktif artinya bahwa proses dalam arti prosedur dan metode yang bersangkutan dapat diulang untuk menguji kembali kebenarannya. Dengan demikian, hubungan antara metodologi penelitian dengan filsafatnya ilmu, yaitu sama-sama berfungsi untuk mendapatkan dan mengembangkan ilmu melalui metode penelitian atau melalui metode ilmiah.

Metode ilmiah merupakan prosedur dalam mendapatkan pengetahuan yang disebut ilmu. Berpikir secara ilmiah berarti berfilsafat. Menurut Judistira K. Garna (2006: 8-9), dikatakan bahwa karakteristik berpikir filsafat itu adalah berpikir yang bersifat:

1. Menyeluruh.

Berpikir secara menyeluruh berarti seseorang itu tidak puas lagi mengenal ilmu hanya dari sisi pandang ilmu tersebut, ingin melihat ilmu dari konstelasi pengetahuan yang lainnya, kaitan ilmu dengan moral, kaitan ilmu dengan agama. Ingin yakin apakah ilmu itu membawa kebahagiaan bagi diri.

2. Mendasar.

Berpikir filsafat itu membongkar tempat berpijak secara fundamental, tidak lagi percaya demikian saja bahwa ilmu itu benar, yang lebih jauh dipertanyakan: mengapa ilmu dapat disebut benar, bagaimana proses penilaian berdasarkan kriteria benar itu dilakukan, apakah kriteria itu sendiri benar, bagaimana proses penilaian menurut kriteria itu dilakukan dan benar itu apa.

3. Spekulatif.

Kecurigaan terhadap filsafat itu bukanlah spekulasi, tetapi itu merupakan suatu dasar yang tidak dapat diadakan. Karena itu suatu lingkaran (bahwa pertanyaan itu melingkar, sedangkan untuk menyusun lingkaran harus dimulai dari satu titik), maka suatu pertanyaan masalah harus mulai dari satu titik bagaimanapun spekulatifnya. Hal penting dalam prosesnya atau dalam analisis dan pembuktian dapat dipisahkan manakah yang spekulasi dan manakah yang 
dapat atau tidak dapat diandalkan. Dengan demikian tugas utama filsafat ialah menetapkan dasar yang dapat diandalkan tersebut. Kemudian timbul pertanyaan yang perlu jawaban, yaitu apakah yang disebut logik, benar, sahih dan apakah teratur, hidup itu bertujuan dan apakah hukum yang mengatur alam dan segenap satwa kehidupan ini.

Metode ilmiah merupakan cara dan sekaligus proses berlangsungnya kegiatan membangun ilmu pengetahuan dari pengetahuan yang masih bersifat prailmiah, yang dilakukan secara sistematis dan mengikuti asas pengaturan prosedural-teknik-normatif, sehingga memenuhi persyaratan kesahihan atau kesahan keilmuan, yang lazim juga disebut memenuhi validitas ilmiah atau secara ilmiah dapat dipertanggungjawabkan.

Didi Atmadilaga (1997: 9-26), mengatakan bahwa dalam metode ilmiah ini terdapat sejumlah kriteria pokok atau karakteristik yang perlu diperhatikan, yaitu:

1. Berdasarkan fakta.

Membangun ilmu pengetahuan itu memerlukan suatu fakta-fakta yang nyata baik yang sudah tersedia maupun yang harus dikumpulkan melalui penelitian, misalnya data berupa data empiris yang terjangkau oleh pengalaman inderawi. Bukan berupa hal-hal yang nyata ada dalam pikiran, dalam bayangan atau menurut cerita orang. Berarti pula bahwa data empiris yang dikumpulkan itu dapat diamati, dapat diukur dan dapat dianalisis lebih lanjut.

2. Pertimbangan Obyektif.

Segala sesuatu yang dilakukan, digunakan, dan diamati berlangsung secara obyektif, sehingga hal yang sama dapat dilakukan atau diulang oleh pihak lain yang berminat dengan metode dan teknik yang sama. Ini berarti bersifat intersubyektif atau impersonal, yaitu tidak terbatas semata-mata kepada orang yang satu saja, melainkan juga oleh orang lain yang mempunyai pengetahuan yang sama. Berarti pula bebas dari prasangka atau pertimbangan yang subyektif.

3. Asas analitik.

Segala sesuatu disoroti secara kritis-analitik dari segi karakteristik, posisi dan kaitan fungsional dengan yang lain, sehingga jelas makna, fungsi dan 
perannya. Hal itu penting untuk mengetahui faktor-faktor yang terlibat dalam suatu masalah, sifat pengaruh masing-masing faktor atau gabungan faktor, juga sifat hubungan yang berlangsung antara faktor yang satu dengan yang lain, dan dengan masalah yang bersangkutan. Asas analitik itu mempunyai makna yang strategis dalam rangka membangun teori yang mampu menjelaskan sesuatu masalah. Juga dalam rangka mengantisipasi atau meramalkan apa yang akan terjadi secara positif menguntungkan, atau untuk mencegah dampak negatifnya.

4. Logika deduktif-hipotetik.

Dalam hal ini metode berpikir yang digunakan adalah logika deduktif, yaitu bertitik tolak pada evidensi-evidensi yang sudah memiliki kebenaran yang pasti, yaitu misalnya hasil penelitian para pakar terdahulu. Dalam silogisme, evidensi tersebut dinamakan premis, yakni untuk mengambil kesimpulan khusus dari premis yang bersifat umum. Proses demikian disebut logika deduktif, dan kesimpulan khusus tersebut dinamakan hipotesis yang kebenarannya sudah diarahkan oleh kebenaran premis-premisnya, sehingga tidak menghasilkan sesuatu yang baru sifatnya. Dapat pula dikatakan bahwa hipotesis adalah suatu abstraksi atau hasil pemikiran rasional yang bersumber dari premis-premis. Adapun kebenarannya itu bersifat sementara, yaitu secara koheren logis, artinya terdapat konsistensi antara hipotesis dengan premispremisnya. Pengembangan hipotesis mempunyai arti strategis yang penting untuk pengembangan teori baru, yang kebenaran ilmiahnya perlu diuji lebih lanjut melalui penelitian.

5. Logika induktif-generalisasi.

Hipotesis yang disinggung di atas adalah hasil pemikiran rasional, maka kebenarannya masih bersifat sementara. Oleh karena itu harus didukung oleh kesesuaian data empiris yang menggunakan logika induktif yang peluang kebenarannya bersifat probabilistik. Logika induktif ini penting artinya dalam rangka menguji hipotesis. Bila didukung oleh data empiris berarti mendapat verifikasi atau dapat diterima kebenaran ilmiahnya. Bila tidak didukung berarti difalsifikasi atau ditolak kebenaran ilmiahnya. 
Sebagaimana yang dipaparkan sebelumnya bahwa sudah menjadi tabiat manusia untuk ingin tahu. Hasrat ini didorong oleh pemberian tertinggi Maha Pencipta kepada manusia, yaitu pikiran. Oleh karena itu, pada akhirnya manusia menamakan dirinya sebagai homo sapiens, yaitu makhluk berpikir. Dengan pikiran ini juga manusia dapat mengungguli semua makhluk ciptaan Tuhan. Tanpa pikiran manusia sama dengan hewan bahkan lebih rendah dari itu, dan walau pun manusia memiliki pikiran, tapi bukan jaminan bagi manusia memiliki pengetahuan secara otomatis, karena rupanya pikiran manusia hanyalah wadah pengetahuan saja, tidak lebih dari itu (Burhan Bungin, 2001: 9) dan (Wila Chandrawila Supriadi, 1997: 1-2).

Dalam hal pengembangan pengetahuan manusia, baik yang bersumber dari pemberitahuan maupun pengalaman, banyak dipengaruhi oleh rasa ingin tahu manusia itu sendiri. Kemudian rasa ingin tahu inilah yang menjadi penentu dari pengembangan ilmu pengetahuan selanjutnya. Sebagai produk berpikir, rasa ingin tahu tak kunjung henti merasuk jiwa manusia. Setelah terpenuhi suatu kebutuhan ingin tahu, timbul kebutuhan ingin tahu lainnya. Hal ini memaksakan manusia untuk terus berpikir dan terus menjawab rasa ingin tahunya. Akibatnya muncul berbagai ragam pikiran dan rasa ingin tahu dan sebagai hasilnya berkembang berbagai macam pengetahuan.

Kebenaran suatu pengetahuan dapat diperoleh melalui 2 (dua) cara, yaitu: (1) mencari kebenaran secara non ilmiah; dan (2) mencari kebenaran secara ilmiah. Sehubungan upaya mencari kebenaran, maka penelitian dan ilmu pengetahuan tidak dapat dipisahkan antara satu sama lainnya. Pengetahuan yang berasal dari upaya mencari kebenaran dengan pendekatan secara epistemogi yang dapat dipertanggungjawabkan kebenarannya. Epistemologi merupakan cabang filsafat, yang sebenarnya mengkaji hakikat pengetahuan yang khusus untuk 4 (empat) pokok persoalan pengetahuan seperti: keabsahan, struktur, batas dan sumber pengetahuan.

Secara etimologi, penguraian berdasarkan pada asal katanya, istilah epistemologi berasal dari bahasa Yunani, yaitu episteme dan logos. Episteme artinya pengetahuan dan logos lazim dipakai untuk menunjukkan adanya 
pengetahuan sistematis, dan secara sederhana epistemologi diartikan sebagai pengetahuan mengenai pengetahuan. Episteme berasal dari kata kerja epistamai, artinya mendudukan, menempatkan atau meletakkan. Secara harafiah episteme berarti pengetahuan sebagai upaya intelektual untuk menempatkan sesuatu dalam kedudukan setepatnya (Pranarka, 1987: 4)

Pengetahuan yang terbentuk dengan pencarian kebenaran melalui kebenaran secara ilmiah (epistemologi) ini, dilaksanakan melalui penelitian ilmiah. Dengan demikian, penelitian sebagai sistem ilmu pengetahuan jelas memainkan peranan penting dalam tubuh ilmu pengetahuan itu sendiri. Adanya kemampuan manusia mengembangkan pengetahuannya dengan cepat, dikarenakan kemampuan berpikir manusia yang mengikuti suatu alur kerangka tertentu. Secara garis besar cara berpikir seperti disebut penalaran (Jujun S. Suriasumantri, 1999: 40). Penalaran merupakan proses berpikir dalam menarik sesuatu kesimpulan yang berupa pengetahuan (Jujun S. Suriasumantri, 1999: 42). Dalam melakukan penalaran ini ada beberapa hal yang perlu diperhatikan sebagai pedoman, seperti cara/teknik dan sarana yang digunakan, sehingga diperoleh pengetahuan yang disebut ilmu.

Penemuan pengetahuan menggunakan salah satu cabang filsafat yang disebut epistemologi. Menurut Judistira K. Garna (2008: 12), dikatakan bahwa untuk mendapatkan pengetahuan secara benar, maka sebagai landasan epistemologi, didasarkan pada 5 (lima) pertanyaan pokok yang perlu diperhatikan, yaitu:

1. Bagaimana prosedurnya;

2. Hal apa yang diperhatikan agar memperoleh pengetahuan yang benar;

3. Apa yang disebut kebenaran;

4. Apa kriteria kebenaran itu; dan

5. Cara, teknik, sarana apa yang membantu memperoleh pengetahuan yang disebut ilmu itu.

Selanjutnya dalam mengkaji objek ilmu tentunya diharapkan jawaban yang benar dan bukan jawaban yang bersifat sembarangan. Masalah inilah yang dalam kajian filsafati termasuk wilayah kajian epistemologi, yang mengkaji persoalan sumber, asal mula dan sifat dasar pengetahuan, bidang, batas dan jangkauan pengetahuan serta validitas dan reliabilitas (reability) dari berbagai 
klaim tentang pengetahuan. Oleh sebab itu, pengetahuan pada hakikatnya merupakan segenap apa yang diketahui tentang suatu objek tertentu, mulai dari pengetahuan sehari-hari, sampai pada pengetahuan yang disebut ilmu. Pengetahuan dapat diibaratkan sebagai sumber jawaban bagi berbagai pertanyaan yang muncul dalam kehidupan manusia.

Sebelumnya telah disebutkan bahwa epistemoligis dalam kajian filsafat pada hakikatnya merupakan cara yang membantu untuk mendapatkan pengetahuan secara ilmiah yang selanjutnya akan disebut ilmu pengetahuan. Ilmu pengetahuan diperoleh lewat metode ilmiah. Sementara metode pada dasarnya cara yang dipergunakan untuk mencapai tujuan, sedangkan tujuan umum penelitian adalah untuk memecahkan masalah, maka langkah-langkah yang akan ditempuh harus relevan dengan masalah yang telah dirumuskan. Hadari Nawawi (1983: 61-93), Nazir (1985: 51-98), dan J. Sitorus (1995: 5-10), mengatakan bahwa lazimnya penggunaan metode yang tepat dalam penelitian adalah:

1. menghindari cara pemecahan masalah dan cara berfikir yang spekulatif dalam mencari kebenaran ilmu, terutama dalam bidang ilmu sosial yang variabelnya sangat dipengaruhi oleh sikap subyektivitas manusia yang mengungkapkannya;

2. menghindari cara pemecahan masalah atau cara bekerja yang bersifat trial and error sebagai cara yang tidak menguntungkan bagi perkembangan ilmu yang sangat dibutuhkan dalam kehidupan moderen; dan

3. meningkatkan sifat obyektivitas dalam menggali kebenaran pengetahuan, yang tidak saja penting artinya secara teoritis tetapi juga sangat besar pengaruhnya terhadap kegunaan praktis hasil penelitian di dalam kehidupan manusia.

Tidak semua penelitian dapat disebut sebagai penelitian ilmiah, karena menurut Nur Indriantoro dan Bambang Supomo (2002: 14-15), bahwa agar suatu penelitian dapat disebut sebagai penelitian ilmiah, selain harus memenuhi metode di atas, penelitian tersebut juga harus memenuhi karakteristik tertentu, yaitu:

1. Menyatakan tujuan secara jelas.

Penelitian ilmiah yang baik adalah penelitian yang menyatakan tujuan penelitian (purposiveness). Tujuan penelitian pada dasarnya adalah menjawab 
suatu masalah atau pertanyaan. Peneliti perlu merumuskan masalah atau pertanyaan penelitian dengan jelas agar dapat menyatakan tujuan penelitian. Proses penelitian selanjutnya difokuskan pada usaha untuk mencapai tujuan yang diharapkan oleh peneliti.

2. Menggunakan landasan teoritis dan metode pengujian data yang relevan. Penelitian ilmiah menggunakan teori-teori yang ketat dan baik (rigor) sebagai landasan untuk menjawab masalah penelitian. Selain itu, penelitian ilmiah memerlukan penerapan metode pemilihan, pengumpulan dan analisis data yang sesuai dan diperlukan untuk menjawab masalah yang diteliti. Landasan teori ini digunakan sebagai pisau analisis data yang dikumpulkan.

3. Mengembangkan hipotesis yang dapat diuji dari telaah teoritis atau berdasarkan pengungkapan data.

Penelitian ilmiah dengan pendekatan deduktif mengembangkan hipotesishipotesis melalui telaah teoritis yang harus dapat diuji (testability) dengan data yang dikumpulkan. Penelitian ilmiah dengan pendekatan induktif mengembangkan hipotesis melalui pengungkapan data yang diteliti.

4. Mempunyai kemampuan untuk diuji ulang (replikasi).

Kriteria penelitian ilmiah ditunjukkan dengan kemampuan suatu penelitian untuk dilakukan pengujian ulang (direplikasi) oleh peneliti-peneliti berikutnya (replicability). Karakteristik ini menggambarkan cara pengembangan ilmu, seperti yang telah diuraikan dalam pembahasan mengenai metode ilmiah, dilakukan secara bertahap melalui pengujian-pengujian.

5. Memilih data dengan presisi dan sehingga hasilnya dapat dipercaya.

Data yang dipilih untuk dikumpulkan dan dianalisis dalam penelitian ilmiah umumnya berupa sampel dari suatu populasi data. Pengujian terhadap data sampel diharapkan memberikan hasil kesimpulan yang berlaku untuk seluruh populasi. Oleh karena itu, penelitian ilmiah menghendaki proses pemilihan data yang memiliki karakteristik representatif dan presisi dengan karakteristik populasinya. Pengujian terhadap data yang secara presisi (precision) menggambarkan realitas populasinya akan menghasilkan kesimpulan yang akurat, dapat dipercaya (confidence) dan andal. 
6. Melaporkan hasilnya secara parsimony.

Laporan penelitian sebaiknya menjelaskan fenomena atau masalah yang diteliti secara simpel atau parsimony. Penyajian laporan secara sederhana bukan berarti mengurangi penjelasan mengenai masalah penelitian dengan baik dan faktor-faktor yang mempengaruhi masalah tersebut. Penjelasan yang berlebihan umumnya cenderung akan mengaburkan fokus masalah dan argumentasi ilmiah yang digunakan untuk menjawab masalah penelitian.

7. Temuan penelitian dapat digeneralisasi.

Penelitian ilmiah juga menghendaki temuannya mempunyai kemampuan untuk dapat digeneralisasi (generalizability), dalam arti bahwa temuan penelitian dapat diterapkan pada lingkup yang lebih luas. Semakin luas kisaran aplikasi dari jawaban masalah yang ditemukan oleh suatu penelitian, akan semakin meningkatkan kontribusi dari temuan tersebut terhadap pengembangan teori atau praktik.

Sifat, karakteristik dan langkah-langkah yang diuraikan di atas, tentunya berlaku pula dalam penelitian kualitatif untuk bidang ilmu hukum, yang ruang lingkupnya mencakup isi dari aturan hukum, maupun implementasi dari aturan hukum itu sendiri. Apabila cakupannya adalah isi dari aturan hukum, maka dalam metode penelitian ilmu hukum dikenal adanya jenis penelitian hukum normatif, dan jika cakupannya adalah implementasi aturan hukum atau identifikasi hukum (tidak tertulis), maka dikenal adanya jenis penelitian sosiologis/empiris.

Menurut Soerjono Soekanto dan Sri Mamudji (2013: 13-14), dikatakan bahwa penelitian hukum normatif adalah penelitian terhadap data sekunder, sedangkan penelitian sosiologis/empiris adalah penelitian terhadap data primer. Soerjono Soekanto (2012: 51), juga menjelaskan bahwa penelitian hukum normatif mencakup penelitian terhadap asas hukum, sistematika hukum, taraf sinkronisasi hukum, sejarah hukum, dan perbandingan hukum, sedangkan penelitian sosiologis/empiris mencakup penelitian terhadap identifikasi hukum (tidak tertulis) dan penelitian terhadap efektifitas hukum.

Terkait dengan jenis penelitian hukum yang diuraikan di atas, maka sebagai salah satu pendekatan yang baru dalam metode penelitian kualitatif 
(termasuk pula dalam bidang ilmu hukum), adalah pendekatan konstruktivis. Paradigma konstruktivis adalah paradigma yang hampir merupakan antitesis dari paham yang meletakkan pengamatan dan objektivitas dalam menemukan suatu realitas atau ilmu pengetahuan. Paradigma ini memandang ilmu sosial sebagai analisis sistematis terhadap socially meaningful action melalui pengamatan langsung dan terperinci terhadap pelaku sosial yang bersangkutan menciptakan dan memelihara atau mengelola dunia sosial mereka (Dedy N. Hidayat, 2003: 3).

Menurut Sarantakos (1993), sebagaimana dikutip Kristi Poerwandari (2007: 22-23), dijelaskan bahwa paradigma konstruktivis menyatakan: (1) dasar untuk menjelaskan kehidupan, peristiwa sosial dan manusia bukan ilmu dalam kerangka positivistik, tetapi justru dalam arti common sense, pengetahuan dan pemikiran awam berisikan arti atau makna yang diberikan individu terhadap pengalaman dan kehidupannya sehari-hari, dan hal tersebutlah yang menjadi awal penelitian ilmu-ilmu sosial; (2) pendekatan yang digunakan adalah induktif, berjalan dari yang spesifik menuju yang umum, dari yang konkrit menuju yang abstrak; (3) ilmu bersifat idiografis bukan nomotetis, karena ilmu mengungkap bahwa realitas tertampilkan dalam simbol-simbol melalui bentuk deskriptif; (4) pengetahuan tidak hanya diperoleh melalui indra karena pemahaman mengenai makna dan interpretasi adalah jauh lebih penting; dan (5) ilmu tidak bebas nilai, karena kondisi bebas nilai tidak menjadi sesuatu yang dianggap penting dan tidak pula mungkin dicapai.

Asumsi dasar konstruktivis bahwa realitas itu tidak dibentuk secara ilmiah, tetapi tidak juga turun karena campur tangan Tuhan, melainkan dibentuk dan dikonstruksikan. Oleh sebab itu, realitas yang sama dapat saja ditanggapi, dimaknai dan dikonstruksi secara berbeda-beda oleh setiap orang, dan berhubung setiap orang mempunyai pengalaman, prefrensi, pendidikan tertentu dan lingkungan pergaulan atau sosial tertentu, maka untuk menafsirkan realitas sosial yang ada di sekelilingnya, dikonstruksikan secara berbeda-beda untuk masingmasingnya. Realitas merupakan bentukan secara simbolik melalui interaksi sosial, sehingga keberadaan simbol atau bahasa menjadi penting dalam membentuk realitas. Berbagai kelompok dengan identitas, pemaknaan, pengalamaan, 
kepentingan, dan sebagainya, mencoba mengungkapkan diri dan selanjutnya akan memberi sumbangan dalam membentuk realitas secara simbolik. Interaksi sosial akan menjadi penting dalam proses ini, sehingga realitas secara simbolik merupakan hasil bersama secara sosial (Butsijournal, https://butsijournal.wordpress.com.: diakses tanggal 25 Mei 2016), dan apabila terjadi konflik antara ilmu dengan pengalaman maka hal itu menyangkut sistem sebagai keseluruhan, tetapi tidak berarti bahwa seluruh sistem harus dihapus, biasanya cukup memperbaharui terjemahan dengan mengganti lambang-lambang tertentu (Peursen, 1989: 82).

Konstruktivis merupakan paradigma filsafat pengetahuan yang menekankan bahwa pengetahuan telah ditangkap manusia adalah konstruksi (bentukan) manusia itu sendiri, maka pengetahuan tidak tentang dunia lepas dari pengamatan, tetapi merupakan ciptaan manusia yang dikonstruksikan dari pengalaman atau dunia selama yang dialaminya. Proses konstruksi pengetahuan berjalan terus menerus dengan setiap kali mengadakan reorganisasi karena adanya suatu pemahaman yang baru. Suatu ilmu pengetahuan setelah mengalami proses yang cukup lama menjadi sebuah ilmu pengetahuan yang lazim bagi manusia untuk dijadikan landasan dalam menjalani kehidupan keseharian. Sebelum dilazimkan oleh manusia, sebuah pengetahuan mengalami penyempurnaan akibat bertambahnya pengalaman baru manusia yang disebut proses reorganisasi ilmu pengetahuan yang berupa pendefinisian kembali, pemantapan konsep dan ilmu pengetahuan yang relatif baku (Turiman Fachturahman Nur, http://rajawaligarudapancasila. blogspot.co.id.: diakses tanggal 25 Mei 2016).

Paradigma konstruktivis pada prinsipnya menyoroti fakta-fakta atau pengalaman-pengalaman sosial yang ada, dan dari pengalaman-pengalaman tersebut dikonstruksikan ke dalam ilmu pengetahuan. Hal ini sejalan dengan konsep-konsep dasar dalam penelitian kualitatif, yang memusatkan perhatiannya pada prinsip umum yang mendasari perwujudan satuan-satuan gejala yang ada dalam kehidupan manusia, atau pola-pola. Gejala-gejala sosial dan budaya dianalisis dengan menggunakan kebudayaan dari masyarakat yang bersangkutan untuk memperoleh gambaran mengenai pola-pola yang berlaku, dan pola-pola yang ditemukan tadi dianalisis lagi dengan menggunakan teori yang objektif. 
Penelitian kualitatif sasaran kajiannya adalah pola-pola yang berlaku yang merupakan prinsip-prinsip yang secara umum dan mendasar berlaku dan menyolok berdasarkan atas kehidupan manusia, maka juga analisis terhadap gejala-gejala tersebut tidak dapat tidak harus menggunakan kebudayaan yang bersangkutan sebagai kerangka acuannya (Parsudi Suparlan, 1994: 6-7).

Terkait dengan ilmu hukum, maka dalam paradigma filsafat konstruktivis, metode penelitian kualitatif hendaknya dapat memberi manfaat atau memperoleh hasil untuk mengkonstruksikan efektifitas dan efisiensi sistem hukum yang meliputi proses pembentukan hukum dan pelaksanaan hukum dalam upaya pencapaian tujuan hukum, yang hal ini tentunya dengan melihat gejala-gejala pada objek dan ruang lingkup yang diteliti. Tujuan hukum yang dimaksudkan disini harus sesuai dengan tujuan Negara Republik Indonesia sebagaimana tertuang dalam Alinea Keempat Pembukaan UUD 1945, yaitu: untuk melindungi segenap bangsa Indonesia dan seluruh tumpah darah Indonesia, memajukan kesejahteraan umum, mencerdaskan kehidupan bangsa, dan ikut melaksanakan ketertiban dunia yang berdasarkan kemerdekaan, perdamaian abadi dan keadilan sosia. Tujuan hukum yang dimaksudkan juga harus didasarkan pada nilai-nilai yang tertuang dalam Pancasila, yaitu nilai ketuhanan, kemanusiaan, nasionalisme, demokratis, dan keadilan.

\section{Simpulan}

Penelitian kualitatif pada dasarnya ditujukan untuk memahami fenomenafenomena sosial dari sudut pandang partisipan, dan yang diteliti adalah kondisi objek alamiahnya, sehingga karakteristik penelitian kualitatif menggunakan lingkungan alamiah sebagai sumber data, memiliki sifat deskriptif analitis, lebih mengutamakan pada proses bukan hasil, bersifat induktif, dan mengutamakan pemaknaan. Hal ini tentunya sesuai dengan pemikiran filsafat konstruktivis yang beranggapan bahwa pengetahuan adalah hasil dari konstruksi (bentukan) manusia itu sendiri, sedangkan manusia mengkonstruksikan pengetahuannya melalui interaksi dengan objek, fenomena, pengalaman dan lingkungannya. Dalam perspektif filsafat konstruktivis, individu mencari pemaknaan terhadap kehidupan 
pada lingkungannya dari pengalaman yang bervariasi dan kompleks, maka proses penelitian sangat mengandalkan informasi pada interaksi yang terkonstruksi di lingkungan, dan sesuai dengan inti dari konstruktivis, maka penelitian kualitatif harus bertujuan untuk mencari makna atau pemaknaan, serta memahami dan menafsirkan makna dari interaksi manusia dengan lingkungan kehidupannya. 


\section{DAFTAR PUSTAKA}

Afid Burhanuddin. "Metodologi Penelitian: Penelitian Kuantitatif dan Kualitatif". https://afidburhanuddin.wordpress.com. diakses tanggal 25 Mei 2016.

Arief Sidharta, B. 2007. Meuwissen tentang Pengembanan Hukum, Ilmu Hukum, Teori Hukum dan Filsafat Hukum. Bandung: Refika Aditama.

-. 2007. Skema Klasifikasi Ilmu-ilmu, Bahan Kuliah S3 Ilmu Hukum. Bandung: Universitas Padjadjaran.

Burhan Ashshofa. 1996. Metode Penelitian Hukum. Jakarta: Rineka Cipta.

Burhan Bungin. 2001. Metodologi Penelitian Sosial. Surabaya: Airlangga University Press.

Butsijournal. "Pendekatan Positivis, Konstruktivis dan Kritis dalam Metode Penelitian Komunikasi”. https://butsijournal.wordpress.com. diakses tanggal 25 Mei 2016.

Dedy N. Hidayat. 2003. Paradigma dan Metodologi Penelitian Sosial Empirik Klasik. Jakarta: Departemen Ilmu Komunikasi FISIP Universitas Indonesia.

Didi Atmadilaga. 1997. Panduan Skripsi, Tesis, Disertasi, Bandung: Pionir Jaya.

Hadari Nawawi, H. 1983. Metode Penelitian Bidang Sosial. Yogyakarta: Gadjah Mada University Press.

Jonathan Sarwono. 2006. Metode Penelitian Kuantitatif \& Kualitatif, Yogyakarta: Graha Ilmu.

Judistira K. Garna. 2008. Filsafat Ilmu, Bandung: Program Pascasarjana Unpad. 2006. Filsafat Ilmu, Bandung: Primaco Akademika dan Judistira Garna Foundation.

-. 2006. Teori Sosial Pembangunan I, Bandung: Primaco Akademika dan Judistira Garna Foundation.

Jujun S. Suriasumantri. 1999. Filsafat Ilmu: Sebuah Pengantar Populer. Jakarta: Harapan.

Kristi Poerwandari, E. 2007. Pendekatan Kualitatif untuk Penelitian Perilaku Manusia. Depok: LPSP3.

Moh. Nazir. (1985). Metode Penelitian. Jakarta: Ghalia Indonesia.

Nur Indriantoro dan Bambang Supomo. 2002. Metodologi Penelitian Bisnis. Yogyakarta: BPFE.

Parsudi Suparlan. 1994. Metode Penelitian Kwalitatif. Jakarta: Program Kajian Wilayah Amerika-Universitas Indonesia. 
Peursen, C.A. van. 1989. Susunan Ilmu Pengetahuan Sebuah Pengantar Filsafat Ilmu. Penerjemah J. Drost. Jakarta: Gramedia.

Pranarka, A.M.W. 1987. Epistemologi Dasar. Jakarta: Centre For Strategic and International Studies (CSIS).

Ronny Hanitijo Soemitro. 2001. Bahan Kuliah Metodologi Penelitian Hukum. Semarang: FH-UNDIP

Sitorus, J. 1995. Metodologi Penelitian Pendidikan. Bandung: Tarsito, Bandung.

Soerjono Soekanto dan Sri Mamudji. 2013. Penelitian Hukum Normatif: Suatu Tinjauan Singkat. Cetakan Ke-15. Jakarta: RajaGrapindo Persada.

Soerjono Soekanto. 2012. Pengantar Penelitian Hukum. Jakarta: UI-Press.

Sugiyono. 2012. Metode Penelitian Kuantitatif, Kualitatif dan R\&D. Bandung: Alfabeta.

Sunny. 2000. "Metodologi Penelitian dan Filsafat Ilmu". Jurnal Pro Justitia. Tahun XVIII-Nomor 4. Oktober. Bandung.

Turiman Fachturahman Nur. "Menggunakan Paradigma Konstruktivisme dalam Penelitian Hukum”.http://rajawaligarudapancasila.blogspot.co.id. diakses tanggal 25 Mei 2016.

Wila Chandrawila Supriadi. (1997). "Pengantar Metode Penelitian", Makalah, Disampaikan dalam Lokakarya Metode Penelitian yang diselenggarakan oleh Lembaga Penelitian Universitas Katolik Parahyangan, di Bandung pada tanggal 1 dan 2 April.

Yuliati Natalia. "Konsep dan Teori: Metode Penelitian Ilmu Administrasi Negara dan Politik". http://ulie-anak-ragil.blogspot.co.id. diakses tanggal 25 Mei 2016.

Zarah Puspitaningtyas. "Metode Penelitian Administrasi Pendekatan Kuantitatif". http://library.unej.ac.id. diakses tanggal 25 Mei 2016. 


\section{BIO DATA PENULIS 1}

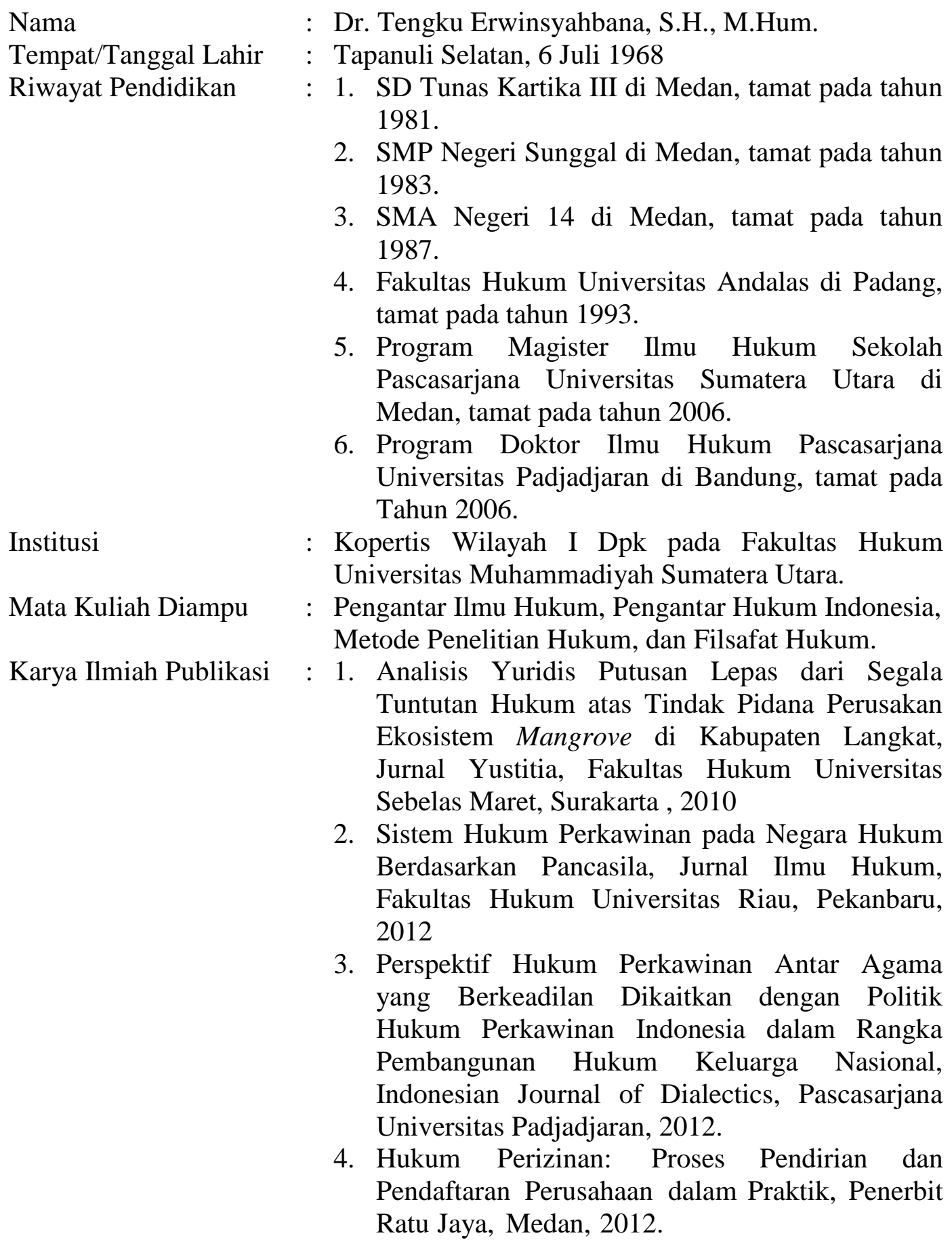




\section{BIO DATA PENULIS 2}

Nama

Tempat/Tanggal Lahir Riwayat Pendidikan

Institusi

Mata Kuliah Diampu

Publikasi Ilmiah
: Dr. Ramlan, S.H., M.Hum.

: Asahan/5 Mei 1971

: 1. SDN 010030 di Sei. Lama Kec. Simpang Empat Kab. Asahan, tamat pada tahun 1987.

2. SMPN Simpang Empat Kab. Asahan, tamat pada tahun 1989.

3. SMA Rakyat Aek Loba Kab. Asahan, tamat pada tahun 1991.

4. Fakultas Hukum Universitas Muhammadiyah Sumatera Utara di Medan, tamat pada tahun 1996.

5. Program Magister Ilmu Hukum Sekolah Pascasarjana Universitas Sumatera Utara di Medan, tamat pada tahun 2005.

6. Program Doktor Ilmu Hukum Pascasarjana Universitas Padjadjaran di Bandung, tamat pada tahun 2014.

: Fakultas Hukum Universitas Muhammadiyah Sumatera Utara.

: Penulisan Karya Tulis Ilmiah, Hukum Dagang, dan Hukum Penanaman Modal.

: 1. Kebijakan Investasi Setelah Berlakunya Otonomi Daerah, Penerbit Jabal Rahmat, Medan, 2007.

2. Intisari Pengantar Hukum Dagang I, Penerbit Jabal Rahmat, Medan, 2009.

3. Prosedur dan Tata Cara Pembuatan Peraturan Desa, Penerbit CV. Ratu Jaya Medan, 2011.

4. Hukum Perizinan: Proses Pendirian dan Pendaftaran Perusahaan dalam Praktik, (Editor: Tengku Erwinsyahbana), Penerbit Ratu Jaya, Medan, 2012.

5. Konsep Hukum Tata Kelola Perikanan; Perlindungan Hukum Industri Perikanan dari Penanaman Modal Asing di Indonesia, Penerbit Setara Press, Malang, Jatim, 2015. 